\title{
DATA ACTIVITIES OF THE RADIATION SHIELDING INFORMATION CENTER*
}

\author{
R. W. Roussin, D. K. Trubey, Betty F. Maskewitz \\ Raliation Shielding Information Center \\ Oak Ridge National Laboratory \\ Oak Ridge, Tennessee, USA
}

\section{ABSTRACT}

\section{DATA ACTIVITIES OF THE RADIATION SHIELDING INFORMATION CENTER}

The Radiation Shielding Information Center (RSIC) is involved in many data activities, with most emphasis being placed on nuclear cross section data. Through cooperation with various agencies, RSIC assists in improving the adequacy of basic evaluated cross section data and packages and distributes various types of data libraries useful in radiation transport analysis. The emphasis of the effort is on the improvement of calculational tools available to the shjelding analyst.

\section{RESUMÉ}

\section{ACTIVITÉS DU "RADIATION SHIELDING INFORMATION CENTER"}

Les activités du Radiation Shielding Information Center (RSIC) concernent de nombreux problémes de données, et plus particulierement de section efficace nucleaires. Par sa coopération avec differents organisations RSIC contribue á l'amelioration des données fundamentales sur les sections efficaces, et distribue plusiers types de librairies de données utiles pour I'analyse du transport des radiations. L'effort principal de RSIC porte sur I'amelioration des techniques utilisées dans l'analyse des blindages de protection.

\section{NOTICE}

This report was prepared as an account of work sponsored by the United States Government. Neither the United States nor the United States Atomic Energy Commission, hor any of their employees, nor any of their contractors, subcontractors, or their employees. thakes any warranty, express or implieci, or assumes any makes any warranty, express or implied, or assumes any pleteness of usefulness of any information, apparatus, product or process disclosed, or represents that its use would not infringe privately owyed rights.

*Research sponsored jointly by the Defense Nuclear Agency, the National Aeronautics and Space Administration, and the U. S. Atomic Energy Commission under contract with the Union Carbide Corporation. 
Roussin, R. W.

In recent years a significant proportion of the activities of the Radiation Shielding Information Center (RSIC) has involved data of various kinds, but primarily neutron and gamma-ray cross-section data. The reason for this work is that the solution of most shielding (radiation transport) problems requires the use of large computer codes and their corresponding cross section libraries which together adequately treat the physics of neutron and gamma-ray interaction and production. As is discussed later, RSIC is involved in various aspects of this general problem by helping to provide evaluated neutron and gamma-ray cross-section data in standard formats, by packaging and distributing computer codes and associated cross section libraries, by packaging and distributing specialized libraries of various types, and by assisting in the compilation of benchmark problem data for testing computation methods and cross section data.

The first two sections which follow outline the role of RSIC in the cooperative effort to develop evaluated cross-section data in Evaluated Nuclear Data File (ENDF) format [1] adequate for shielding calculations. There follows a description of the activities associated with the acquisition and distribution of specialized data libraries for use in treating various types of radiation transport problems.

This work involves collaboration with others, including the National Neutron Cross Section Center (NNCSC) at Brookhaven National Laboratory, the Shielding Subcommittee of the Cross Section Evaluation Working Group (CSEWG), and the Defense Nuclear Agency (DNA).

\section{CLEARINGHOUSE FOR CSEWG SHIELDING EVALUATIONS}

RSIC has always been concerned with cross sections and the problems associated with the proliferation of data in non-standard formats. Thus, the development of the ENDF program was supported by RSIC from inception. An RSIC staff member participated in the early planning stages, but more significant contributions were possible once the CSEWG Shielding Subcommittee was organized early in 1967. Since then, RSIC participation has been extensive, with emphasis on areas of vital interest to the shielding community.

RSIC continues to collaborate with NNCSC at Brookhaven National Laboratory and the CSEWG Shielding Subcommittee. The Center's rol $\equiv$ in this activity is to assist in the acquisition, checkout, and review of "shielding" cross sections in ENDF format which may ultimately be placed in the ENDF/B file. In this context, "shielding" cross sections are evaluations performed in the shielding, radiation effects or weapons communities which are likely to have an emphasis on gamma-ray production cross sections, gamma-ray interaction cross sections, and neutron cross sections in the energy range of interest for shielding with detailed energy and angular distribution resolution.

By early 1972, twelve evaluations had been received by RSIC, processed through checking codes, modified to conform to the ENDF format as necessary, and forwarded to NNCSC, which prepared and distributed a packet for Phase Ij

\footnotetext{
TPhase I testing eliminates clerical and format errors and results in a data set which seems reasonable. Phase II testing involves the use of the data to compare radiation transport calculations with integral experiments and results in knowledge about the adequacy of the data.
} 
Roussin, R. W.

data testing. To assist in preparation of Phase I testing materials, RSIC helped coordinate the updating of computer codes PLOTFB and CHECKER [2] to handle gamma-ray production data (ENDF files 12-16) in the present formats. The revised codes are now available.

The ENDF/B-III library, released officially in January 1972, contained for the first time evaluations which included photon production data. These evaluations are listed in Table I.

In addition to the above activities, RSIC has coordinated the writing of a computer code [3] to translate, and subsequently has translated, the UKAEA library to ENDF/B format for NNCSC.

Through active participation in the CSEWG Shielding Subcommittee, RSIC seeks to help meet the needs of data requirements for various problem areas. For example, the Shielding Subcommittee is presently considering possible formats for handling time- as well as resonance-dependent photon production data in anticipation of the need for these types of data.

\section{THE DEFENSE NUCLEAR AGENCY WORKING CROSS SECTION LIBRARY}

RSIC maintains and distributes the DNA cross-section library [4]. This is a working library in ENDF format whose content can be modified and revised as often as the evaluator deems such changes to be necessary. The key to this approach is a selected evaluator, the person responsible for making the original evaluation for a particular element or elements. $\mathrm{He}$ is then responsible for authorizing changes in evaluations for those elements. The evaluated data are for those materials of interest to DNA, whose cross-section values are in a state of rapid change, and emphasis is placec on neutron energies up to $20 \mathrm{MeV}$ and on secondary gamma-ray production. Evaluations of interest to DNA which are not in a state of rapid change are found in the ENDF/B library, which is available in the USA from NNCSC at Brookhaven National Laboratory.

The clearinghouse for the DNA program is RSIC. Initial versions of evaluations are received, processed through checking codes to eliminate obvious format errors, and modified as necessary in collaboration with the evaluator. Next, DNA Phase I data testing is performed whereby selected reviewers are provided with listings, output from checking codes, graphics, etc., and are asked to review the data and feed back their comments. These will be relayed to the evaluator and, upon his instruction, appropriate changes will be made. Changes are initiated only by the evaluator and each change is documented so that users can, at any time, refer to an identifiable data set when reporting results of their calculations.

Because the data are apt to be revised with some frequency, each evaluation is designated by a DNA MAT number and a MOD number. The DNA MAT number is a unique identification number for an evaluation and is equal to the corresponding NNCSC-assigned ENDF MAT number plus three thousand for those evaluations which are submitted for inclusion in the ENDF/B library. The MOD number designates the number of times the DNA evaluation has been modified since its initial availability through RSIC. The current contents of the DNA library are listed in Table II.

Since the DNA library is in ENDF format and is available for consideration by CSEWG to become part of the ENDF/B library, the DNA program offers a good opportunity for improving the state of shielding cross sections. 
Roussin, R. W.

This is illustrated by noting that of the twelve "shielding" evaluations in ENDF/B-III listed in Table I, nine came from the DNA library.

The data, along with available documentation, are distributed upon request. The users are asked to feed back any comments they have, based on experience in using the data.

\section{THE RSIC DATA LIBRARY COLLECTION}

The performance of digital computer calculations, in general, may be thought of as a three-part process, which can be identified with three components. The first part is the acquisition and preparation of a data base to be processed. The second is the development and use of a computer program to operate on the input data, perform certain logical operations, and finally produce output data. The output data, the third component, is then analyzed, often with the aid of machine manipulation. The output, after reduction, finally appears in reports and journal articles.

In radiation transport calculations, the three components normally take the form of (1) cross-section libraries, (2) radiation transport computer codes, and (3) radiation transport results (output).

Since inception, RSIC has been deeply involved, through its computer code library, in the second component mentioned above. In addition, a data library collection has been developed such that it can include not only component (1), cross-section libraries, but also component ( 3 ), radiation transport results. The data sets are packaged in a manner analogous to the RSIC code collection. [5] Each data sft, packaged as a unit, carries a Data Library Collection (DLC) number. As with the code packages, a particul.ar data package does not remain static but is subject to revision, updating, and expansion as required. Such changes are announced in the RSIC Newsletter.

Data libraries were first announced as available from RSIC near the end of 1968. At that time it became evident that a collection of data libraries would be an extremely helpful companion to the RSIC Computer Code Collection. The main objective is the interchange of technology among installations engaged in radiation transport research, development, and applications. The current contents of the Data Library Collection are listed in Table III.

The philosophy behind the packaging and distributing of these data libraries is to preserve and make available in an easily usable form, data which may be useful to those utilizing or performing radiation transport calculations. Since this usually involves the use of large computer programs, several of these libraries are multigroup cross sections in the format utilized by many such programs.

There are problems which lead to great differences in opinion in regard to the desirability of collecting, packaging, and distributing reference data, especially standard multigroup libraries for general use. There is the danger that the prestige of a center can give the impression that data is of better quality than it actually is. Experience demonstrates that in many cases a standard, fixed energy group library cannot be used to obtain accurate radiation energy spectra. Examples of this are deep transport calculations in materials such as air, iron, and sodium. Even using a complex weighting spectrum with a standard group structure (such as 100 
Roussin, R. W.

$$
-5-
$$

groups) will not provide accurate results. In these cases the most important requirement is that the group structure must resclve energy range where cross sections vary rapidly. On the other hand, experience has shown that standard group structure libraries will work for hydrogenous systems and many complex mixtures where cross section details are not very irnportant.

Where available, RSIC seeks to obtain multigroup data sets which have been shown to handle adequately a particular problem or class of prcblems for which a standard multigroup approach is inadequate. This has led to the question, "Is it better to make available poor data or no data?" Probably a better question is, "Is it better to make available state-of-theart data, i.e., the best obtainable at present, or no data?" We believe the answer to this question should be to make available the best data obtainable, even though there is some risk that the recipient may not fully appreciate the limitations. The recipient, however, must be the person responsible for the effects of its use.

In addition to the cross section sets, certain radiation transport results have also been packaged. In some cases, the volume of data from a problem may be so great that it is not feasible to publish it all. One can then publish samples of the results but place the entire output on magnetic tape for distribution, as needed, by RSIC. Processing codes for performing editing, plotting, interpolation, and certain integrations accompany the data. An example is the DLC-5 Hallmark data (see Table III).

Documentation is very important. The abstract format used for the DLC sets is similar to that used to describe the code packages. Care was taken to make the format include all of the information necessary for adequately describing the contents and purpose of each data library. The abstracts of the DLC sets are published in Ref. [6]. The main purpose of the abstracts is to give to a potential data library user several criteria for deciding whether or not he wishes to obtain the data.

\section{ADDITIONAL ACTIVITIES}

A continuing project, in cooperation with the American Nuclear Society, is to collect, edit, and publish reference data in the form of "benchmark problems." The objective is to compile in convenient form a limited number of well-documented problems in radiation transport which will be useful in testing computational methods used in shielding analysis. The problem solutions, having been determined by several methods, should be representative of the state of the art. The problem descriptions are published in looseleaf form [7] so that revisions and additions can be easily made. Contributions to the benchmark collection are sought by the Benchnark Problem Group. In conjunction with the benchmark work, data sets are packaged which allow the recalculation, with a particular calculational method, of already published results. An example is the data in DLC- 8 which allows the calculation of American Nuclear Society Shielding Benchmark Problem Number 3. This kind of calculation is useful for testing a new computer code or theoretical treatment.

It has always been RSIC policy to discuss with users their needs and recommend codes and data libraries. Insofar ar possible, we assist those who are implementing codes and data at their installations. In cases where we lack experience to advise in particular problem areas, we call upon other experienced personnel locally and elsewhere to help them. This takes the 
Roussin, R. W.

form of offering advice on solving particular problems, as well as helping to diagnose problems in implementing calculational procedures.

As always, RSIC relies on members of the shielding community to share their ideas, codes, and data so that technology as a whole may be advanced.

Table I. Evaluations in ENDF/B Version III which contain gamma-ray production data

\begin{tabular}{ll}
\hline Material & ENDF/B MAT \\
\hline Nitrogen & 1133 \\
Oxygen & 1134 \\
Aluminum & 1135 \\
Lead & 1130 \\
Hydrogen & 1148 \\
Chlorine & 1149 \\
Potassium & 1150 \\
Silicon & 1151 \\
Calcium & 1152 \\
Berylium & 1154 \\
Sodium & 1156 \\
Iron & 1180 \\
\hline
\end{tabular}

Table II. Contents of the DNA Working Cross-Section Library

\begin{tabular}{llrrc}
\hline Material & \multicolumn{1}{c}{ Evaluators } & DNA & Date of \\
\hline Nitrogen & Young, Foster - LASL & MAT & MOD & MOD \\
Oxygen & Young, Foster - LASL & 4133 & 3 & $2-72$ \\
Aluminum & Foster, Young - LASL & 4134 & 1 & $2-72$ \\
Lead & Fu, Perey - ORNL & 4135 & 2 & $2-72$ \\
Hydrogen & Stewart, LaBauve, Young - LASL & 4136 & 2 & $4-72$ \\
Silicon & Drake, Kinsey - BNL & 4148 & 1 & $2-72$ \\
Calcium & Fu, Perey - ORNL & 4151 & 1 & $2-72$ \\
Beryllium & Howerton, Perkins - LLL & 4152 & 2 & $5-72$ \\
Tantalum & Howerton, Perkins, MacGregor - LLL & 4154 & 0 & $2-72$ \\
Iron & Penny, Kinney, Wright, Perey, Fu - ORNL & 4179 & 0 & $2-72$ \\
U-238 & Howerton, MacGregor - LLL & 4180 & 1 & $8-72$ \\
U-235 & Howerton, MacGregor - LLL & 4187 & 0 & $7-72$ \\
\end{tabular}


TABLE III. CONTENTS OF THE RADIATION SHIELDING INFORMATION CENTER

DATA LIBRARY COLLECTION, SEPTEMBER 1972

\begin{tabular}{|c|c|c|c|}
\hline $\begin{array}{l}\text { Data Library } \\
\text { Designation }\end{array}$ & Contributor $\mathbf{a}$ & Form & Data Type/Computer Code/Component \\
\hline DLC-1/LEP & ORNL-N & $\begin{array}{l}\text { 16-mm microfilm } \\
\text { magnetic tape } \\
\text { machire listings }\end{array}$ & $\begin{array}{l}\text { Bertini's low-energy intranuclear cascade results; output from ANALYSIS Codes } I \text { and II and } \\
\text { from EVAP (ORNL-TM-1225, ORNL-3433). }\end{array}$ \\
\hline DLC-2/100G & $\begin{array}{l}\text { ORWL-H } \\
\text { ORNL-H }\end{array}$ & Magnetic tape & $\begin{array}{l}\text { 100-group } P_{8} \text {-expanded neutron cross sections for input to ANISN/DOT/DTF-IV/MORSE; produced fr } \\
\text { ENDF/B-III data By SUPERTOG (1972); energy range from } 14.92 \mathrm{MeV} \text { to thermal. }\end{array}$ \\
\hline DLC-3/MECC-7 & ORNL-N & $\begin{array}{l}\text { 16-m microfilm, } \\
\text { magnetic tape, } \\
\text { machine listings }\end{array}$ & $\begin{array}{l}\text { Bertini's medium-energy intranuclear cascade results; output from ANALYSIS codes I and II and } \\
\text { from EVAP (ORNL-TH-3336, ORNL-3433). }\end{array}$ \\
\hline DLC-4/HPICO & ORNL-H & Magnetic tape & $\begin{array}{l}\text { Gamma-ray photoelectric and pair-production data in OGRE format (ORNL-3805); data same as } \\
\text { in DLC-7. }\end{array}$ \\
\hline DLC-5/HALLHARK & ORHL-N & Magnetic tape & $\begin{array}{l}\text { Output from DOT, O5R-ACTIFK, and OGRE; Straker's time-dependent air-over-ground results for } \\
\text { point isotropic sources; handling codes allow production of results for arbitrary energy spec } \\
\text { neutron sources range from } 15 \mathrm{MeV} \text { to } 3.3 \mathrm{keV} \text {; results include neutron and secondary gamma-ray } \\
\text { fluxes (ORNL-4289, vol. II). }\end{array}$ \\
\hline DLC-6/GAHLIB & $\begin{array}{l}\text { ORIL-H } \\
\text { ORRL-N }\end{array}$ & Hagnetic tape & $\begin{array}{l}\text { ORNL GAH-II library in GGC-4 format; } 99 \text { neutron group, } \mathrm{P}_{3} \text {, data for } 114 \text { nuclides based in par } \\
\text { On ENDF/B-II data; neutron energy range } 14.92 \mathrm{MeV} \text { to thermal (ORNL-TH-3334). }\end{array}$ \\
\hline DLC-7/HPICE & LLL & Magnetic tape & $\begin{array}{l}\text { Livermore gamma-ray interaction data in ENDE/B format; recommended as ENDF/B reference data; } \\
\text { covers elements having } \mathrm{Z} \text { values of } 1-83,86,90,92 \text {, and } 94 \text {, and gamma rays having energles } \\
\text { in the range from } 1 \text { keV to } 100 \mathrm{HeV} \text { (UCRL-50400, vol. VI; UCKL-50174, Sect. II, May 1969). }\end{array}$ \\
\hline DLC-8/BP-3 & ORNL-N & Cands & $\begin{array}{l}\text { 22-group } P_{5} \text {-expanded cross sections for air in the ANISN/DOT/MORSE format; data used by Stra) } \\
\text { for Benchmark Problem No. } 3 \text {; neutron spectrum constructed from point sources in infinite air } \\
\text { covering energy ranges from } 15 \text { MeV to thermal (ORNL-RSIC-25). }\end{array}$ \\
\hline DLC-9/FARS & ORNL-N & Magnetic tape & $\begin{array}{l}P_{8} \text {-expanded coupled cross sections ( } 104 \text { neutron groups, } 18 \text { gamma-ray groups) for } H, C, N, O \text {, } \\
\text { Mg, Al, Si, Ca, and Fe; data format for ANISN/DOT/DTF-IV/MORSE; compiled by F. Schmidt for } \\
\text { concrete calculations (ORWL-RSIC-26); neutron energy range, } 15 \mathrm{HeV} \text { to thermal; ganma-ray } \\
\text { energy range, } 10-0.02 \mathrm{HeV.}\end{array}$ \\
\hline DLC-10/AVKER & ORNL-N & Magnetic tape & $\begin{array}{l}\text { Data library of neutron fluence-to-kerma factors for many elements; retrieval program will } \\
\text { compute energy group values for ary composition for use with group fluence to calculate dose } \\
\text { or heat ing (ORML-TH-2558);neutron energy ranges from } 19.2 \text { HeV to } 0.023 \mathrm{eV} \text {. }\end{array}$ \\
\hline
\end{tabular}


TABLE III. (continued)

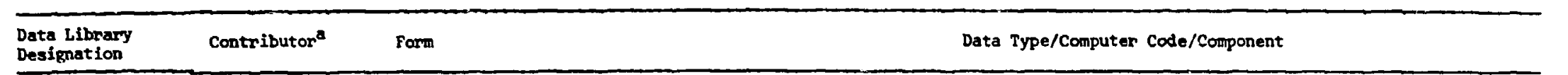

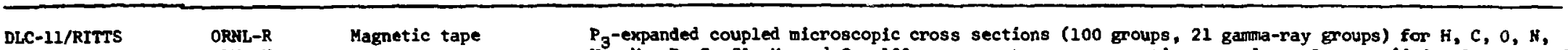

ORKL-N Magnetic tape

CTC

$\mathrm{Na}, \mathrm{Mg}, \mathrm{P}, \mathrm{S}, \mathrm{Cl}, \mathrm{K}$, and $\mathrm{Ca} ; \mathrm{l00}$-group neutron cross-section set alone also provided, plus coupled tracroscopic cross sectious for standard man, $3 k i n$, bone, tissue, brain, lung, red marrow and muscle; data format for ANISN/DOT/MORSE; neutron energy range, $15 \mathrm{MeV}$ to thermal; gauma-ray energy range, 14 to 0.01 Hiel (ORNL-TM-2291).

$\begin{array}{lll}\text { DLC-12/POPLIB } & \begin{array}{l}\text { ORNL-H } \\ \text { ORNL-N }\end{array} & \text { Hagnetic tape } \\ \text { DLC-13/GARLIB } & \text { NASA-LE } & \text { Magnet ic tape }\end{array}$

Compendium of neutron-induced secondary gama-ray yield and production cross-section data; data library for PSR-1:/POPOP4 code; current library has 243 data sets (1971) (CTC-INF-1004).

32-group resonance-region neutron capture and scattering cross sections for moderated tungst'en and uranium slabs; produced by the GAROL code; group fluxes calculated by GAROL also included for further collapsing of the group structure; energy range, $1.234 \mathrm{keV}$ to $0.414 \mathrm{eV}$ (HASA TH $\mathrm{X}-1909)$.

DLC-14/AIR ORNL-N Magnetic tape

ANISN input data for a $P_{3} S_{16}$ coupled (22 neutron groups, 18 gamma-ray groups) transport calculations for a 12.2- to 15 - MeV point source in air; output from ANISN run also provided; allows users to repeat the Straker-Gritzner infinite-air calculations (ORNL-4464).

DLC-15/STORH-ISRAEL LASL

Nagnetic tape

Los Alamos gamma-ray interaction data in ENDF format for elements from $\mathrm{z}=1$ to 100 ; energy range, $1 \mathrm{keV}$ to $100 \mathrm{MeV}$; essentially equivalent to DLC-7 but has additional data for many derived cross sections (Nuclear Data, A7, 565-681).

$\begin{array}{lll}\text { DiC-16/CGBB } & \begin{array}{l}\text { ORNL-R } \\ \text { ORNL-Y }\end{array} & \text { Magnetic tape } \\ \text { DLC-17/NOX } & \text { ORNL-N } & \text { Magnetic tape }\end{array}$

123-group $P_{\text {}}$ expanded neutron cross sections for input to XSDRN; produced from ENDF/BII data by SUPLRTOG-THERMOS ( 30 thermal groups); energy range, $14.92 \mathrm{MeV}$ to thermal.

$P_{5}$-expanded coupled cross sections ( 86 neutron, 33 gamma-ray groups) for $N$ and 0 , data format fór ANISN, etc. produced from DNA MAT 4133, MOD 1 nitrogen and DNA MAT 4134, MOD 0 oxygen with SUPERTOG, BUSECT and MUG, used to analyze neutron transport and secondary gamma-ray production and transport in liquid $\mathrm{N}$ and air (ORNL-3635, GA-9429, DNA 2831F, ORNL-TH-3768), neutron energy range $15 \mathrm{MeV}$ to thermal, gamma-ray energy range 10 to $0.01 \mathrm{MeV}$.

DLC-18/NAB ORNL-R Magnetic tape

group, $P_{3}$-expanded neutron cross sections for Na and Al, data format for ANISN, etc., produced from ENDF/B-III Na and Al with SUPERTOG, used to analyze ORNL LMFBR sodium benchmark expeximent (ORNL-TM-3800), energy range 15 KeV to thexmal.

\footnotetext{
Library contrikiutors: CTC, Computing Technology Center, Union Carbide Corp., Oak Ridge, Tenn.; NASA-LE, NASA Levis Research Center, Cleveland, Chio; ORHL-M, Mathematics Division, ORHL-N, Neutron Physics Division, ORNL-R, ORNL Reactor Division; LLL, Law'ence Livermore Laboratory, Livermore, Calif.; LASL, Los Alamos Scientif:c Laboratory, Los Alamos, N. M.
} 


\section{REFERENCES}

1. M. K. Drake, Editor, "Data Formats and Procedures for the ENDF Neutron Cross Section Library," BNL 50274 (T-601) ENDI-102, Vol. I (1971), and D. J. Dudziak, Compiler, "ENDF Furmats and Procedures for Photon Production and Interaction Data," LA-4549 (ENDF-102, Rev., Vol. II).

2. Odelli Ozer, Editor, "Description of the ENDF/B Processing Codes and Retrieval Subroutines," ENDF-110 (Revised September 1970).

3. R. Q. Wright, S. N. Cramer, and D. C. Irving, "UKE - A Computer Code for Transiating Neutron Cross Section Data from the UKAEA Nuclear Data Format to the Evaluated Nuclear Data File Format," ORNiL-TM-2880, ENDF-134 (March 1970).

4. R. W. Roussin, "The Defense Nuclear Agency Working Cross Section Library: Description and Contents," ORNL-RSIC-34 (August 1972).

5. Betty F. Maskewitz, "Abstracts of the Computer Code Packages Assembled by the Radiation Shielding Information Center, ORNL-RSIC-13, Vol. I III.

6. R. W. Roussin, "Abstracts of Data Library Packages Assembled by the Radiation Shielding Information Center," ORNL-RSIC-30 (1972).

7. A. E. Profio, Editor, "Shielding Benchmark Problens," ORNL-RSIC-25 (Sup. 1, 1970). 